Article

\title{
Green, Green, It's Green: A Triad Model of Technology, Culture, and Innovation for Corporate Sustainability
}

\author{
Zhaojun Yang ${ }^{1, *}$ (D) Jun Sun $^{2}$, Yali Zhang ${ }^{3}$ and Ying Wang ${ }^{2}$ \\ 1 School of Economics and Management, Xidian University, Xi'an 710126, China \\ 2 College of Business and Entrepreneurship, University of Texas Rio Grande Valley, Edinburg, TX 78539-2999, \\ USA; jun.sun@utrgv.edu (J.S.); ying.wang01@utrgv.edu (Y.W.) \\ 3 School of Management, Northwestern Polytechnical University, Xi'an 710072, China; zhangyl@nwpu.edu.cn \\ * Correspondence: zhaojunyang@xidian.edu.cn
}

Received: 17 July 2017; Accepted: 1 August 2017; Published: 3 August 2017

\begin{abstract}
In the global trend of sustainable development and tightening legal environment, enterprises need to integrate their various resources to promote green innovation and organizational performances. This study conceptualizes green information system (IS) infrastructure as the hardware resource and green culture as the software resource. Based on the resource-alignment perspective, it examines their direct effects on green innovation effectiveness as well as indirect effects through the mediation of IS-culture fit, innovation-IS fit and innovation-culture fit. Survey observations were collected from over 300 organizations in China, the largest emerging economy under tremendous ecological and developmental pressures. The results suggest that green IS infrastructure and green culture has positive direct impacts on green innovation effectiveness. Meanwhile, innovation-IS fit, innovation-culture fit and IS-culture fit serve as positive, negative and non-significant mediators, respectively. In addition, a multi-group analysis reveals that organization size moderates the mediating rather than direct relationships, and small/medium and large enterprises face their own pros and cons in green innovation. Theoretical and practical implications of the findings are discussed.
\end{abstract}

Keywords: corporate sustainability; strategic endeavor; green information systems; green innovation; green culture; perceived alignment; resource-based view; triadic relationships; organizational performances

\section{Introduction}

"Green, green, it's green, they say on the far side of the hill. Green, green, I'm going away to where the grass is greener still."

-Johnny Rivers

To leave a green world to later generations, sustainable development is the only viable path. In the current global advocacy of green economy, each country faces the environmental challenge to keep up in the "green race" [1]. In this context, technology-based green innovation at the organizational level is widely regarded as the essential means to the end of ecological competitiveness [2-6]. Many studies have confirmed that the implementation of green innovation not only helps the environment, but also contributes to organizational performance, competitiveness, and corporate green image or brand [7-10].

Among the studies that examined the organizational performance related to green innovation, some include its adoption drivers as the antecedents [11-13]. For those organizations that have decided to adopt or are in the process of implementing green innovation, however, it is also important to understand what existing factors and conditions may affect green innovation practice 
and effectiveness. Researchers identify the relevant factors and conditions as follows: absorptive capacity [14], stakeholders and culture [15], green organizational identity [16], corporate environmental ethics [4], and green intellectual capital [8]. In particular, the emergence of green information systems (IS) is seen as an important organizational resource that contributes to the well development and functioning of green innovation [17-19].

A case study suggested that the success of organizational innovations depends on the mutual alignment between new technologies and pre-existing conditions such as organizational culture and structure [20]. Though researchers have examined green culture and green IS quite extensively, there is a lack of empirical findings on the alignment between them. Thus, the main purpose of this study is to investigate the synergetic effect of technological and cultural factors on green innovation.

Organizations need to assemble and integrate capabilities/resources into manageable bundles [21]. Such organizational capabilities cannot be evaluated in isolation as their values manifest through mutual integration and interplay [22]. In addition, organizational innovation research reveals that organizational culture also plays an important role [23-26]. Despite the presence of a few studies on green culture $[27,28]$, it has not been examined together with other organizational capabilities, especially green IS.

From a holistic perspective, this study aims to examine the relationships among green innovation, IS and green culture. In addition to the direct effects that green IS and green culture may have on green innovation, there are potential indirect effects through the mediation of the alignments between two of them. Based on literature review, this study develops a research model and tests it with empirical observations collected from organizations. The findings may enrich the green innovation literature by examining the roles of green IS and green culture together, and provide helpful insights for organizations to integrate their cultural, technological and innovative efforts in their green endeavor.

\section{Key Components of Green Endeavor}

\subsection{Green Innovation}

In recent years, green innovation has captured the attention of researchers and practitioners as an emerging organizational innovation. The appearance of the term is rooted in eco-innovation concept that describes "new products and processes which provide customer and business value but significantly decrease environmental impacts" [29]. Since then, there have been quite a few studies on the topic with the same or similar terms such as environmental innovation and sustainable innovation [30-38]. Largely synonymous and interchangeable, these terms can be categorized under the umbrella term of "green innovation".

There are different types of innovations towards sustainable development, such as: technological innovation, organizational innovation, institutional innovation and social innovation [39]. Organizational innovation requires the integration of hardware (e.g., technological infrastructure) and software (e.g., organizational culture) resources in an organization to cope with different innovation types (e.g., radical vs. incremental) and modes (e.g., component vs. architectural) [40]. Therefore, green innovation is a complex organizational endeavor that has been examined in different contexts, such as green research and development [41], green supply chain management [42], green corporate image [43] and green organizational identity [16].

Researchers mainly investigate green innovation from three aspects: its own components (i.e., construct dimensions), antecedents (i.e., explanatory variables), and consequences (i.e., outcome variables). The primary challenge for empirical studies is in construct measurement, especially for the multi-dimensional construct of green innovation. In addition to the direct ecological effort, the green innovation also requires necessary changes in products, processes, and organizational structures [44]. Thus, it is not appropriate to measure green innovation as a unidimensional construct. For instance, the measurement of eco-innovation should include four aspects: input, intermediate output, direct output and indirect impact [44]. A similar analytical framework explores the diversity 
of eco-innovations along several key dimensions including design, user, product service and governance [45]. Despite the difference in details, it is clear that green innovation is a multidimensional concept including technical and non-technical elements.

In addition, researchers are interested in the factors that affect green innovation, or its antecedents. Green innovation may involve the factors at different levels, and organization-level factors play a fundamental role in comparison with industry-, region-, and country-level factors. Organizational factors deserve close attention because the green innovation effort is never purely policy-driven, but a result of balancing between long-term sustainability and short-term profitability in managerial praxis [11,38]. Organizations need to get ready internally for green innovation to embrace the external challenges and opportunities of environmental regulations and market demands [11]. Empirical evidence confirmed that a firm's internal initiatives, environmental regulations and market demands are all important to its green innovation success [12,46]. According to the technology-organization-environment (TOE) framework, technical characteristics such as complexity, relative advantage, and compatibility also affect green innovation adoption in addition to organizational, market and regulatory factors [13].

Green innovation is likely to have different implications on the consequences from general innovation as well. Most existing studies treated green innovation as one subtype of general organizational innovation without paying much attention to its unique features and impacts, such as multi-dimensional performances (e.g., economic, environmental and social), technology support (e.g., green information systems and green supply chain management), and cross-sector collaboration (e.g., suppliers, customers, and stakeholders). This makes it difficult for existing green innovation research to highlight its difference with existing organizational innovation research. However, green innovation differs from general innovation from innovation process and driving factors to consequences and performance [47-49]. Because innovation processes within enterprises targeting higher environmental goals are somewhat unique from those motivated by other objectives, green innovation is more challenging than other types of organizational innovation [49].

Therefore, green innovation is a complex organizational endeavor that requires the design and implementation of eco-friendly products. In addition to the "hardware" of technological infrastructure, the effort requires the support of "software", especially the organizational culture related to green innovation, or green culture. The alignment between such hardware and software largely determines whether green innovation is successful or not [40].

\subsection{Green Culture}

Extant literature studies the effects of organizational culture on green innovation from different aspects. First, it is found that green culture affects employees' awareness related to green innovation in terms of their own orientations toward and perceived organizational commitment to green endeavors [50]. Employees in organizations of which the culture is aligned with the ecological movement are likely to participate in sustainability effort, leading to enhanced organizational performances and positive environmental impacts.

Regarding the relationship between green culture and organizational strategy, researchers found that strong environmental culture helps organizations implement green strategy [51]. Moreover, how well environmental values are integrated into organizational culture influences the effect of green strategy on ecological and business performance [52]. Organizational culture comprises different aspects that play different roles in environmental/sustainability management, and organizations need to cultivate green culture to guide employee behavior in different aspects of their collective effort [53]. A case study of nine companies in various industries analyzed how they defined, developed, and integrated sustainability into organizational culture and strategy as well as employees' mentality, and gave a practical guidance on how organizations build green culture by taking advantage of their unique capabilities, knowledge and purposes to cater to both long-term sustainability goal and short-term profitability requirement [28]. Another study in the healthcare field found that the 
transformation of organizational cultures is inseparable from employee involvement, innovation effort, new decision-making models and an infrastructure for significant cultural changes [27].

The theories of organizational innovation suggest that organizations' internal factors are essential to green innovation. According to the resource-based view, such internal factors include strategy, structure, and core capabilities [54]. In addition, intangible factors such as personnel-based resources also play the role that cannot be ignored [11]. As an intangible resource, organizational culture is related to the internal climate that supports or impedes organizational creativity and innovation [24,54-56]. On the one hand, an organizational culture proactive to green innovation often leads to competitive advantage [57]. On the other hand, bad or mismatched culture may negatively affect the organization's environmental management, green innovation and relevant performance [53].

From the theoretical perspective, the existing studies highlight the importance of organizational culture to sustainable development and environmental management. However, there is still a lack of empirical studies on the relationship between organizational culture and green innovation. Based on the current literature of organizational culture, therefore, this study will investigate the research question of whether and how green culture may affect green innovation.

\subsection{Green IS Infrastructure}

Green IS pertains to the establishment and utilization of information systems to facilitate ecological goals with functions such as environment auditing, teleconferencing and virtual collaboration [58,59]. Enabled by green IS infrastructure, the utilization of such functions is conducive to green innovation and corporate sustainability [5]. Whereas organizational culture can be regarded as an intangible "software" resource that provides necessary environment for environmental management, green IS infrastructure can be regarded as a tangible "hardware" resource that enables green IS functions and supports green innovation. Based on the resource-based view, six IS competencies (i.e., IT/innovation governance, business-IS linkages, project management, knowledge management, collaboration, and ambidexterity) can make a difference in the conception, implementation and development of process innovations [60].

There are a few empirical studies on the relationship between general IS and business innovation. An exploratory case study examined the roles that enterprise information systems play in within-organization innovation [61]. For cross-organization innovation, IS may also facilitate the effort by enhancing the communication with other organizations such as suppliers and clients [62], as well as the quality of service through service innovation [63].

Nevertheless, there is still a lack of empirical studies on the relationship between green IS and green innovation. Although green IS and green innovation sharing the common goal of sustainable development, they play different roles in organizations. In addition to the resource-based view that treats green IS as a "hard" resources, the general IT alignment literature has also investigated the relationship between system characteristics and organizational characteristics (e.g., strategy and culture) in terms of how to implementing technology to facilitate and support long-term endeavor $[64,65]$.

\section{Mutuality among Key Components}

The above literature review suggests that green culture and green IS can be regarded as the soft (i.e., intangible) and hard (i.e., tangible) resources that facilitate the strategic endeavor of green innovation. Regarding the relationships between organizational resources and strategic activities, the general alignment theory provides an overarching framework. There are generally six perspectives of alignment: fit-as-matching, fit-as-mediation, fit-as-moderation, fit-as-profile-deviation, fit-as-covariation, and fit-as-gestalts [66]. Green culture and green IS provides the social environment and technological infrastructure necessary for green innovation, the success of which largely depends on how well the two types of resources meet its requirement. In this sense, fit-as-matching gives appropriate theoretical mechanism and analytical scheme to conceptualize and operationalize the alignment among them, as depicted in Figure 1. 


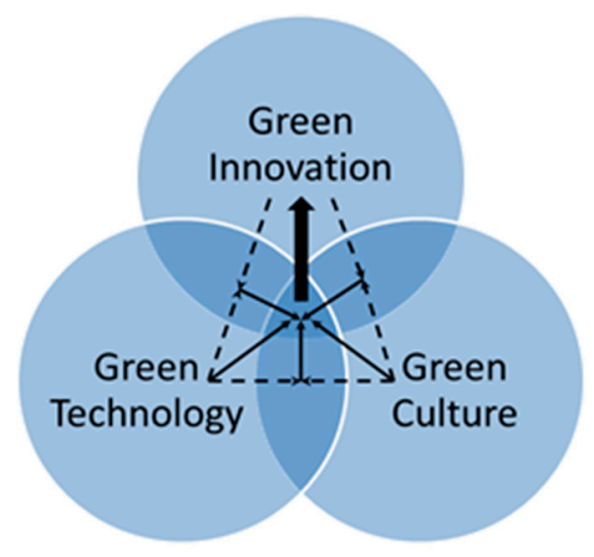

Figure 1. Conceptual framework.

\subsection{Organizational Innovation and IS Infrastructure}

For organizations, the implementation of information technology (IT) is increasingly seen as the key enabler of organizational innovation rather than just for cost-efficiency consideration [67]. IT may promote innovation as an intellectual technology that interacts with the intellect of the human users [68]. The technology extends the intellects of its users, leading to an ongoing cycle of organizational innovation and change [67].

From the perspective of knowledge management, organizations may facilitate process-, product-, service-, technology- and management-related aspects of innovation by aligning technology with innovation [69]. From an IT capability view, organizations may utilize technological advances to innovate and differentiate, leading to IT-enabled business value [70]. Thus, the implementation of IT promotes the process, service and management innovation in organizations [71-73].

Information technology supports organizational innovation through the complex interaction among different factors, rather than a simple technology adoption or diffusion process. A study based on the resource-alignment view confirmed that the interaction between IT capital and innovation yields a positive influence on organizational performances [74]. At the strategic level, the alignment between IT strategy and open innovation strategy is found to enhance organizational performance [65].

To summarize, researchers suggest that organizations need to align technology capability with innovation requirement to achieve optimal resource allocation and competitive advantage. Although there are not many studies on green IS and green innovation, the existing literature concerning the relationship between general IS and corporate innovation still provides a theoretical basis.

\subsection{Organizational Innovation and Organizational Culture}

Similarly, there are not many studies on the alignment between green culture and green innovation. However, researchers confirmed the significant role that organizational culture plays in organizational innovation $[75,76]$. The consensus is that organizations should establish a supportive cultural environment conducive to the promotion of innovation $[25,26]$. Nevertheless, different types of organizational endeavor call for different strategies of cultural cultivation [77]. For instance, adhocracy culture fosters the pioneer strategy to lead the market (e.g., developing new products) and hierarchical culture promotes the imitator strategy to follow a pioneer [26].

Furthermore, organizational culture is a multi-dimensional construct. It is found that the consistency and mission dimensions lead to direction and stability, whereas involvement and adaptability dimensions facilitate flexibility and change [78]. This dual nature requires the cultivation of organizational culture through internal integration, training or learning, and external cooperation or adaptation [79], leading to ambidextrous organizational culture [80]. In terms of organizational innovation, ambidextrous organizational culture affects the development of new products, services 
and processes through contextual ambidexterity [80]. Once formed, such radical innovation culture is likely to positively impact business performance [81].

Green culture is also likely to have this dual characteristics, namely internally integration of shared vision, and external adaptation to the changes in policy and market. Naturally green culture can be considered as a moderating factor that promotes green innovation if both are mutually aligned.

\subsection{IS Infrastructure and Organizational Culture}

Following a values-based approach, a literature review on the linkage between IT and culture revealed that the existing research had examined both IT's impact on culture and culture's impact on IT, leading to a theory that there is a mutual influence between organizational culture and IT as well as a potential conflict of values [82]. A reorientation of values arises from the reconciliation of the conflict, which requires organizations to appropriately address the relationship between IT value and culture fit.

There are four stages of theory development regarding the relationship between organizational culture and IT infrastructure: (1) technological determinism that IT impacts organizational culture; (2) organizational imperative for cultural adaptation; (3) interactionist view of culture and IT; and (4) emergent process of IT-culture alignment [64]. Although country-level culture is considered relatively stable, organizational culture is considered malleable. Both Stages (3) and (4) suggest the importance of interaction and integration between IT infrastructure and organizational culture for their alignment optimal to corporate performances.

For green innovation, the same logic may apply: green culture and green IS may interact and align with each other through mutual influence and accommodation. In the long term, the implementation and adoption of green IS will shape organizational culture to be more eco-friendly, which will in turn enhance green IS usage at different levels in an organization.

\section{Research Model and Hypotheses}

Green innovation, green culture and green IS in organizations are closely related to each other, and researchers must examine their relationships in a holistic system rather than separately. The alignment between green innovation and green IS, or innovation-IS fit, captures how well green IS implementation supports the accomplishment of green innovation goal. Once an organization establishes the strategy of green innovation, it needs to implement appropriate green IS functionalities to facilitate the endeavor. A mismatch is likely to prevent employees from fully utilizing green IS to fulfil green innovation. The alignment between green culture and green innovation, or culture-innovation fit, indicates how green innovation is in line with green culture. For example, an organization of a stronger green culture faces less resistance from employees in the adoption of green innovation approaches such as paperless office, electronic workflow and teleconferencing. Meanwhile, such green innovation endeavor may as well strengthen green culture in the long run. Similarly, the alignment between green culture and green IS, or culture-IS fit, reflects the degree of cohesion between green IS implementation and green culture. If an organization has a relatively weak green culture, for instance, it probably needs to take effort to justify green IS expenditure and persuade employees to use the newly implemented functionalities.

As the two different types of foundations, green IS infrastructure and green culture are likely to have direct impacts on green innovation. In addition, there may be indirect effects through the mediation of alignments among the three components of green endeavor. The premise is that if the components are aligned with each other, the supportive roles that green IS infrastructure and green culture play will be optimized in terms of green innovation effectiveness as the outcome variable. The direct and indirect relationships are hypothesized in the research model as shown in Figure 2. 


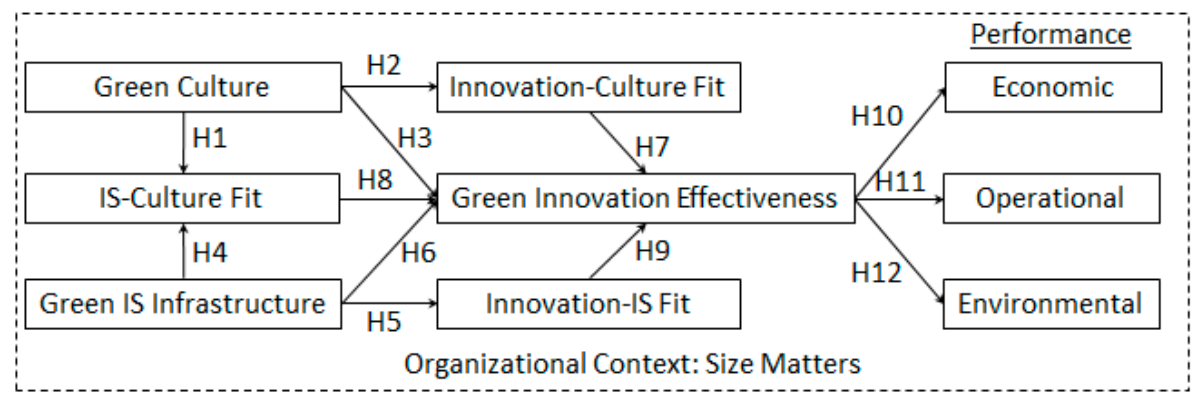

Figure 2. Research model.

Compared with other types of organizational innovations, green innovation emphasizes the use of technology [38]. For such a technology-enabled innovation, organizational context in terms of size can make a difference as it largely determines resource availability and structural agility [83,84]. It is found that small and medium enterprises are usually more agile but at the same time face more resource constraints than big organizations in adopting technologies [85]. Therefore, organization size is likely to moderate the hypothesized relationships in the model, which are to be discussed in details below.

\subsection{Green Culture-Related Hypotheses}

Organizational culture is considered essential for the success of an organization, especially in the IT-driven global environment [86]. For sustainable-development-oriented organizations, the establishment of a good green culture enhances environmental management and performance. IS-related organizational culture affects system usage and user behavior [87]. Organizations that establish green culture and implement green IS, therefore, need to pay attention to the alignment between two.

Similarly, organizational culture in many studies is also seen as an important factor that influences organizational innovation [54-56]. Certain aspects of organizational culture can significantly affect organizational innovation [88]. This requires innovation-driven organizations to consider the impact of organizational culture and pay attention to aligning organizational culture with innovation activities.

Organizational culture comprises multiple dimensions in terms of adaptability, consistency, involvement, and mission, which play somewhat different roles in organizational effectiveness $[78,89]$. The same dimensions of green culture also pertain to green innovation [27]. An organization of relatively high level of adaptability tends to change its operation, technology and structure to survive the ecological tide. Consistency and involvement largely determine the efficiency of collective effort of organizational members in green endeavor, as the two dimensions indicate agreement and participation. Finally, mission provides direction and guidance to the collective effort, such as green IS implementation and use, as it is related to an organization's purpose as shared by employees.

In an organization with a good green culture, therefore, employees are more receptive to green concepts and practices, and more active in green innovation activities. In addition, the organization is more likely to seriously examine and continuously adapt its culture to green innovation. Hence the following hypotheses:

Hypothesis 1 (H1). Green Culture is positively associated with IS-Culture Fit.

Hypothesis 2 (H2). Green Culture is positively associated with Innovation-Culture Fit.

Hypothesis 3 (H3). Green Culture is positively associated with Green Innovation Effectiveness. 


\subsection{Green IS-Related Hypotheses}

In an organization, information system infrastructure and organizational culture are closely related with each other. Claver et al. [24] suggested that system implementation and adoption shape relevant organizational culture in terms of informatic culture and informational culture. The former is a material symbol of the culture that entails the acceptance of using IT as a critical organizational activity, whereas the latter also concerns how employees capture and utilize information and data through organizational behavior.

Southern and Murray [90] believed that the use of IS contributes to a better organizational culture. Meanwhile, Silvius, Smit and Driessen [91] also found that certain aspects of organizational culture such as "governance" and "partnership" play important roles in information system adoption and implementation. Information systems and green culture may combine and form green informational culture, which can be seen as an organizational resource as well as an organizational capacity [92]. When an organization has better IS infrastructure, therefore, it is more likely to achieve the desired alignment between green IS and green culture.

From the resource-based view, information systems provide necessary infrastructure for organizational innovation [60,61]. For cross-organization innovation, information systems facilitate service innovation by enhancing communication and quality of service [62,63]. Green innovation usually involves the collaboration within and cross organizations to accomplish ecological goals, which requires green IS to provide necessary technical support. Therefore, green IS infrastructure is critical to Green Innovation, as indicated in the following hypotheses:

Hypothesis 4 (H4). Green IS Infrastructure is positively associated with IS-Culture Fit.

Hypothesis 5 (H5). Green IS Infrastructure is positively associated with Innovation-IS Fit.

Hypothesis 6 (H6). Green IS Infrastructure is positively associated with Green Innovation Effectiveness.

\subsection{Alignment-Related Hypotheses}

The basic premise of resource-based view is that an organization must effectively integrate various resources to achieve its managerial goals. Consistent with the ecological modernization theory, environmental innovation strategy and resource alignment between partners have positive impacts on green innovation performance, whereas resource alignment also moderates the relationship between environmental innovation strategy and green innovation performance [93]. The three aspects of green innovation, including green process innovation, green product innovation and green management innovation, all require the effective integration of organizational resources $[9,94,95]$.

Researchers also found that cultural factors as intangible resources make a difference in organization creativity and innovation [24,54-56]. Therefore, the establishment of environment-friendly culture consistent with sustainable development objectives facilitates green innovation. Organizational culture comprises the values, principles, traditions and conventions shared by the members of an organization to regulate their behavior [78]. Compared with other tangible organizational resources, therefore, green culture is unique in that it provides a common context for all employees to participate in green activities.

For the same ecological goal, the alignment between green culture and green IS reflects the integration of two tangible and intangible resources, the alignment between green innovation and green culture reflects the integration of intangible resources and business operations, and the alignment between green innovation and green IS reflects the integration of tangible resource and business operations. The degree of alignment or misalignment affects how employees utilize organizational resources and carry out business operations, leading to different levels of performance. Therefore, all aspects of alignment contribute to green innovation in organizations, as hypothesized below: 
Hypothesis 7 (H7). Innovation-Culture Fit is positively associated with Green Innovation Effectiveness.

Hypothesis 8 (H8). IS-Culture Fit is positively associated with Green Innovation Effectiveness.

Hypothesis 9 (H9). Innovation-IS Fit is positively associated with Green Innovation Effectiveness.

\subsection{Performance-Related Hypotheses}

The bottom-line question for green innovation is how it eventually affects organizational performances related to sustainable development. It is found that the product and process aspects of green innovation have direct impacts on environmental performance, whereas the managerial aspect has somewhat more salient influence competitive advantage [9]. More specifically on competitive advantage, researchers found that green innovation activities contribute to operational efficiency and financial outcome in addition to ecological consequence [96-99]. Therefore, green innovation effectiveness is likely to enhance the environmental, economic and operational aspects of organizational performance, leading to the following hypotheses:

Hypothesis 10 (H10). Green Innovation Effectiveness is positively associated with Economic Performance.

Hypothesis 11 (H11). Green Innovation Effectiveness is positively associated with Operational Performance.

Hypothesis 12 (H12). Green Innovation Effectiveness is positively associated with Environmental Performance.

\section{Methodology}

To test the research model, this study collected survey observations from organizations that pursue ecological goals in their operations. The target population is the employees of those organizations in China. Known as the "world's factory", this largest emerging economy faces the challenge of environment protection and embraces the opportunity of sustainable development.

\subsection{Measurement}

A survey questionnaire was developed to capture the constructs in the research model from the perspective of employees. Among the nine constructs, three concern different aspects of green endeavor (i.e., green IS, green culture, and green innovation), three pertain to their alignments (i.e., green IS-culture fit, innovation-IS fit and innovation-culture fit), and the other three are about organizational performances (i.e., environmental performance, economic performance and operational performance). In addition to the direct impacts of green endeavor variables, the alignment variables further carry their indirect effects, leading to partial mediations. The operationalization of the constructs, therefore, needs to tap their different natures based on previously validated instruments.

Appendix A lists all the measurement items, which were of five-level Likert scale in the questionnaire. Green IS Infrastructure was measured with items adapted from the study by Gholami et al. [100]. Measures of Green Culture were adapted from Denison and Mishra's [78] items. Measurement of Green Innovation came from studies by Chen et al. [94], Chiou et al. [9] and Damanpour and Aravind [95]. Measures of different aspects of alignment were derived from Lin and Huang's [101] scale. Environmental performance was measured with the items developed by Green et al. [102] and Lee et al. [103]. Economic performance scale was originally developed by Daugherty et al. [104]. The measurement of operational performance was based on instruments developed by Gholami et al. [100] and Chiou et al. [9]. 


\subsection{Survey Method and Sample}

Under tremendous developmental and environmental pressures, China has tightened its regulations on pollution and emission, especially on the enterprises in big cities. Based on a cluster sampling on the enterprises in Beijing, Shanghai, Guangzhou, and Xi'an, electronic and paper questionnaires were given to the contacts of 500 companies (one per each). At the beginning, there is a filtering question on whether the organization has implemented green IS to facilitate green innovation. For most enterprises in China, being green is not a fashion but a necessity: they either meet the requirement or get phased out. To further minimize the influence of social desirability bias, participants were told that there are no correct or wrong responses and ensured of anonymity and confidentiality.

Altogether, 368 valid responses were obtained, of which 194 were gathered from on-site interviews $(53 \%)$ and 174 were returned by emails in Word files (47\%). Table 1 reports the profiles of participating organizations and respondents. Among the organizations, about $42 \%$ were from traditional industries such as manufacturing, energy and real estate, and about 33\% were from emerging industries such as logistics, IT and service, with the rest from other industries. About half of them were large organization of 1000 or more employees, and the rest were small and medium enterprises.

Among the respondents, male-to-female ratio was a little bit above two. Almost half of them were from the administration departments, and the rest were from production, marketing, as well as research and development. The distribution of organizational roles reflects the composition of managerial levels in organizations: about $60 \%$ were at the operational level, and $40 \%$ were at middle and senior levels.

Table 1. Profiles of participating organizations and respondents.

\begin{tabular}{lcc}
\hline \multicolumn{1}{c}{ Characteristics } & Frequency & \% (N = 368) \\
\hline Organization Type & 65 & \\
- Manufacturing & 30 & 17.7 \\
- Energy & 58 & 8.2 \\
- Real Estate & 8 & 15.8 \\
- Logistics & 69 & 2.2 \\
- IT & 45 & 18.8 \\
- Service & 93 & 12.2 \\
- Other & & 25.3 \\
Size (Number of Employees) & 193 & \\
- Small and Medium (<1000) & 175 & 52.4 \\
- Large ( $\geq 1000)$ & & 47.6 \\
Respondent Gender & 254 & \\
- Male & 113 & 69 \\
- Female & 1 & 30.7 \\
- Not Reported & & 0.3 \\
Managerial Level & 24 & \\
- Senior & 117 & 6.5 \\
- Middle & 226 & 31.8 \\
- Operational & 1 & 61.4 \\
- Not Reported & & 0.3 \\
Home Department & 164 & \\
- Administration & 84 & 44.6 \\
- Research and Development & 63 & 22.8 \\
- Production & 57 & 17.1 \\
- Marketing & & 15.5 \\
\hline
\end{tabular}

Possible response bias due to different data collection methods was assessed. The MANOVA test comparing on-site versus online responses showed no significant difference (Wilks' lambda $=0.827$, $p=0.196$ ). On-site responses were typically obtained immediately, but online responses usually take some time from several hours to a few weeks after emailed invitations. As the responses were not sensitive to response time, nonresponse bias is not a big concern [105]. 
This study also evaluates common method bias with Harman's one-factor test and unmeasured latent method construct technique [106-108]. The exploratory factor analysis result on all measures indicated that the first unrotated factor explained $41.269 \%$ of total variance (less than $50 \%$ ), whereas all factors with Eigen value larger than 1 explained $67.088 \%$ of total variance. Table 2 reported the confirmatory factor analysis result comparing method-only model, trait-only model, and trait/method model. The trait-only model yielded the best goodness-of-fit, confirming that trait-based variance was stronger than common method variance.

Table 2. Unmeasured latent method construct (ULMC) model comparison.

\begin{tabular}{lcccccc}
\hline \multicolumn{1}{c}{ Model } & $\chi \mathbf{2}$ & df & $\chi \mathbf{~} \mathbf{2 / d f}$ & RMSEA & CFI & NFI \\
\hline Method-Only (1-Factor) & 8870.004 & 2153 & 4.12 & 0.092 & 0.625 & 0.56 \\
Trait-Only (16-Factor) & 3981.704 & 2037 & 1.955 & 0.051 & 0.891 & 0.803 \\
Trait/Method (17-Factor) & 4370.532 & 2072 & 2.109 & 0.055 & 0.872 & 0.783 \\
\hline
\end{tabular}

\section{Results}

Table 3 gives the results of descriptive, reliability and correlational analyses for all the constructs used in this study. On average, the responses were moderately positive as the means were above three (i.e., neutral) but below four (i.e., agree), and exhibited reasonable dispersions as the standard deviations were above 0.5 but below 1 . Indicating the internal consistency of responses, all the reliability coefficients were above 0.7 . The correlation coefficients were higher among those of the same concepts (i.e., culture, IS, innovation, alignment, and performance) than among others, which also support convergent validity. The evaluation of discriminant validity was based on the comparison between correlation coefficients and the square root of the average variance extracted (AVE). The square root of AVE for each construct was larger than its correlation coefficients with the other constructs, supporting discriminant validity.

In the research model, the three main green constructs in terms of technology, culture and innovation are second-order formative constructs comprising first-order reflective constructs as their indicators. The multicollinearity of formative indicators was assessed to make sure that they are distinct from each other. As shown in Table 4, all the tolerance values were above 0.25 and variance inflation factors (VIF) were below 5 . There was evidence for the discriminant validity among formative indicators as they did not co-vary too much with each other in predicting their higher-order constructs. 
Table 3. Descriptive, reliability and correlational analyses.

\begin{tabular}{|c|c|c|c|c|c|c|c|c|c|c|c|c|c|c|c|c|c|c|}
\hline Concept_Variable & Mean (SD) & $\alpha$ & V1 & V2 & V3 & V4 & V5 & V6 & V7 & V8 & V9 & V10 & V11 & V12 & V13 & V14 & V15 & V16 \\
\hline V1: Culture_Involvement & $3.63(0.82)$ & 0.79 & 0.84 & & & & & & & & & & & & & & & \\
\hline V2: Culture_Consistency & $3.65(0.77)$ & 0.81 & 0.67 & 0.85 & & & & & & & & & & & & & & \\
\hline V3: Culture_Adaptivity & $3.79(0.69)$ & 0.73 & 0.67 & 0.65 & 0.81 & & & & & & & & & & & & & \\
\hline V4: Culture_Mission & $3.72(0.75)$ & 0.83 & 0.55 & 0.65 & 0.71 & 0.87 & & & & & & & & & & & & \\
\hline V5: IS_Pollution Prevention & $3.77(0.80)$ & 0.88 & 0.47 & 0.49 & 0.48 & 0.45 & 0.90 & & & & & & & & & & & \\
\hline V6: IS_Product Stewardship & $3.77(0.78)$ & 0.86 & 0.51 & 0.49 & 0.54 & 0.51 & 0.78 & 0.88 & & & & & & & & & & \\
\hline V7: IS_SustainableDevelopment & $3.84(0.74)$ & 0.86 & 0.49 & 0.51 & 0.51 & 0.50 & 0.70 & 0.77 & 0.84 & & & & & & & & & \\
\hline V8: Innovation_Product & $3.68(0.72)$ & 0.85 & 0.50 & 0.56 & 0.53 & 0.53 & 0.57 & 0.60 & 0.60 & 0.80 & & & & & & & & \\
\hline V9: Innovation_Process & $3.80(0.66)$ & 0.85 & 0.51 & 0.52 & 0.57 & 0.55 & 0.56 & 0.60 & 0.62 & 0.71 & 0.79 & & & & & & & \\
\hline V10: Innovation_Management & $3.72(0.70)$ & 0.88 & 0.52 & 0.56 & 0.57 & 0.63 & 0.62 & 0.64 & 0.69 & 0.66 & 0.78 & 0.79 & & & & & & \\
\hline V11: Fit_Innovation-Culture & $3.76(0.69)$ & 0.91 & 0.54 & 0.53 & 0.55 & 0.56 & 0.53 & 0.53 & 0.62 & 0.48 & 0.46 & 0.54 & 0.86 & & & & & \\
\hline V12: Fit_IS-Culture & $3.75(0.68)$ & 0.90 & 0.54 & 0.52 & 0.51 & 0.53 & 0.58 & 0.58 & 0.66 & 0.52 & 0.48 & 0.60 & 0.80 & 0.84 & & & & \\
\hline V13: Fit_Innovation-IS & $3.72(0.68)$ & 0.91 & 0.49 & 0.51 & 0.51 & 0.5 & 0.56 & 0.58 & 0.62 & 0.53 & 0.51 & 0.59 & 0.71 & 0.77 & 0.85 & & & \\
\hline V14: PerformanceEconomic & $3.76(0.67)$ & 0.88 & 0.43 & 0.39 & 0.43 & 0.39 & 0.42 & 0.48 & 0.47 & 0.49 & 0.52 & 0.52 & 0.55 & 0.51 & 0.54 & 0.83 & & \\
\hline V15: PerformanceOperational & $3.77(0.67)$ & 0.89 & 0.44 & 0.41 & 0.53 & 0.53 & 0.44 & 0.47 & 0.49 & 0.47 & 0.53 & 0.58 & 0.62 & 0.61 & 0.55 & 0.77 & 0.83 & \\
\hline V16: PerformanceEnvironmental & $3.85(0.62)$ & 0.87 & 0.43 & 0.41 & 0.45 & 0.44 & 0.40 & 0.42 & 0.51 & 0.49 & 0.57 & 0.57 & 0.62 & 0.60 & 0.57 & 0.66 & 0.67 & 0.81 \\
\hline
\end{tabular}

Note: SD, standard deviation; the bold is the square root of AVE. 
Table 4. Multicollinearity among formative indicators of second-order constructs.

\begin{tabular}{lcc}
\hline \multicolumn{1}{c}{ Formative Indicator } & Tolerance & VIF \\
\hline Green Culture & & \\
- Involvement & 0.467 & 2.142 \\
- Consistency & 0.426 & 2.345 \\
- Adaptability & 0.351 & 2.850 \\
- Mission & 0.400 & 2.499 \\
Green IS & & \\
- Pollution Prevention & 0.367 & 2.722 \\
- Product Stewardship & 0.293 & 3.414 \\
- Sustainable Development & 0.388 & 2.580 \\
Green Innovation & & \\
- Product & 0.452 & 2.212 \\
- Process & 0.324 & 3.084 \\
- Management & 0.356 & 2.813 \\
\hline
\end{tabular}

Note: VIF, variance inflation factor.

The main statistical analysis tool used is partial least square (PLS-SEM) to accommodate the reflective-formative higher-order nature of latent constructs $[109,110]$. Following the common practice of item packaging when reliability coefficients are all acceptable, the index score of each dimension of Green Culture, Green IS Infrastructure and Green Innovation Effectiveness was calculated based on the average of item responses, and used as a formative indicator.

Figure 3 shows the standardized estimates of path coefficients for all the observations. The two control variables, organization size $(\beta=-0.025, p>0.05)$ and organization age $(\beta=0.056, p>0.05)$, did not make much difference on the core construct of Green Innovation Effectiveness. Green Innovation Effectiveness had positive effects on all the economic, operational and environmental aspects of organizational performance. The expected results supported the bottom-line premise that green innovation is important for corporate sustainability. The direct effects of both Green IS Infrastructure $(\beta=0.481, p<0.01)$ and Green Culture $(\beta=0.380, p<0.01)$ on Green Innovation Effectiveness were also significantly positive as hypothesized.

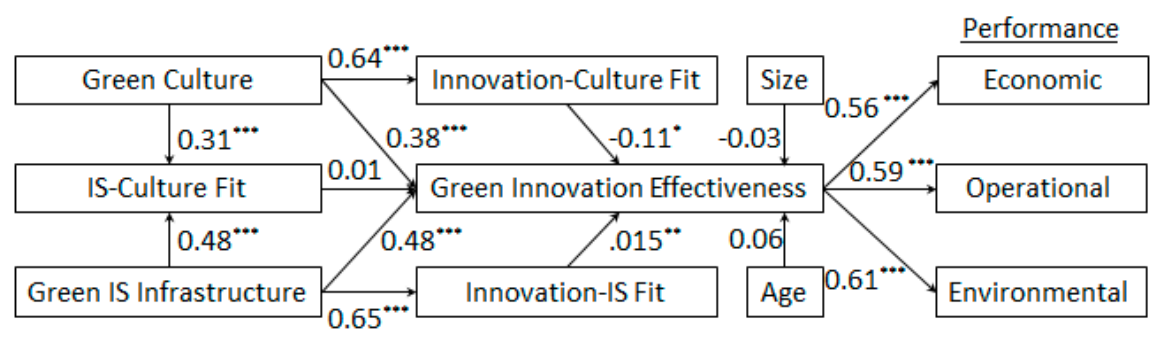

Note: ${ }^{*}$ - significant at 0.1 level, ${ }^{\cdots}$ - significant at 0.05 level, ${ }^{\cdots}{ }^{\cdots}$ - significant at 0.01 level

Figure 3. Estimated model.

Each of the two exogenous variables also contributed to the alignment between them (Green Culture $\rightarrow$ IS-Culture Fit: $\beta=0.313, p<0.01$; Green IS Infrastructure $\rightarrow$ IS-Culture Fit: $\beta=0.481, p<0.01$ ) as well as their alignments with Green Innovation in a positive way (Green Culture $\rightarrow$ Innovation-Culture Fit: $\beta=0.637, p<0.01$; Green IS Infrastructure $\rightarrow$ Innovation-IS Fit: $\beta=0.648, p<0.01$ ). The effects of three alignment variables on Green Innovation Effectiveness, however, were quite mixed. In terms of their effects on Green Innovation Effectiveness, Innovation-IS Fit $(\beta=0.152, p<0.05)$ was positive and significant, Innovation-Culture Fit $(\beta=-0.113, p<0.1)$ was negative and marginally significant, and IS-Culture Fit was not significant $(\beta=0.008, p>0.1)$. Together, the results suggest partial mediation for Innovation-IS Fit and Innovation-Culture Fit, the former as a facilitator but the latter as a neutralizer 
in terms of their effects on green innovation. There is almost no mediation for the alignment between Green IS Infrastructure and Green Culture, probably due to their counter effect with each other.

Table 5 also reports the standardized estimates of path coefficients for the split samples based on organization size (big vs. small-and-medium). The multi-group analysis indicated that organization size noticeably moderated four of 12 hypothesized relationships. All the four relationships pertained to Green Innovation Effectiveness: three were related to its relationships with alignment constructs and one with Environmental Performance. Whereas none of the alignment constructs had significant effects on Green Innovation Effectiveness for large organizations, Innovation-IS Fit had a significantly positive effect, Innovation-Culture Fit had a significantly negative effect, and IS-Culture Fit had a non-significant effect for small and medium enterprises. The relationship between Green Innovation Effectiveness and Environmental Performance was significantly positive for both groups, but the effect was more salient for big organizations than for small and medium enterprises.

Table 5. Standardized partial least square estimates.

\begin{tabular}{|c|c|c|c|c|}
\hline Path & All & Big & S\&M & Diff \\
\hline Control: Size $\rightarrow$ Innovation Effectiveness & -0.025 & - & - & - \\
\hline Control: Age $\rightarrow$ Innovation Effectiveness & 0.056 & 0.050 & 0.008 & 0.042 \\
\hline H1: Green Culture $\rightarrow$ IS-Culture Fit & $0.313^{* * *}$ & $0.316^{* * *}$ & $0.299 * *$ & 0.017 \\
\hline H2: Green Culture $\rightarrow$ Innovation-Culture Fit & $0.637^{* * *}$ & $0.633^{* * *}$ & $0.659^{* * *}$ & 0.026 \\
\hline H3: Green Culture $\rightarrow$ Innovation Effectiveness & $0.380^{* * *}$ & $0.350 * * *$ & $0.362 * * *$ & 0.012 \\
\hline H4: Green IS Infrastructure $\rightarrow$ IS-Culture Fit & $0.481^{* * *}$ & $0.542^{* * *}$ & $0.436^{* * *}$ & 0.106 \\
\hline H5: Green IS Infrastructure $\rightarrow$ Innovation-IS Fit & $0.648^{* * *}$ & $0.680^{* * *}$ & $0.619^{* * *}$ & 0.061 \\
\hline H6: Green IS Infrastructure $\rightarrow$ Innovation Effectiveness & $0.481^{* * *}$ & $0.399^{* * *}$ & $0.535^{* * *}$ & 0.136 \\
\hline H7: Innovation-Culture Fit $\rightarrow$ Innovation Effectiveness & $-0.113 *$ & 0.027 & $-0.202 * *$ & $0.229 * *$ \\
\hline H8: IS-Culture Fit $\rightarrow$ Innovation Effectiveness & 0.008 & 0.146 & -0.052 & 0.198 * \\
\hline H9: Innovation-IS Fit $\rightarrow$ Innovation Effectiveness & $0.152 * *$ & 0.023 & $0.208^{* * *}$ & $0.185 *$ \\
\hline H10: Innovation Effectiveness $\rightarrow$ Economic Performance & $0.563^{* * *}$ & $0.610^{* * *}$ & $0.532 * * *$ & 0.078 \\
\hline H11: Innovation Effectiveness $\rightarrow$ Operational Performance & $0.592 * * *$ & $0.660^{* * *}$ & $0.544^{* * *}$ & 0.116 \\
\hline H12: Innovation Effectiveness $\rightarrow$ Environmental Performance & $0.607^{* * *}$ & $0.697^{* * *}$ & $0.536^{* * *}$ & $0.161^{* *}$ \\
\hline
\end{tabular}

Note: S\&M-Small and Medium. Statistical significance is based on two-tailed t-test: ${ }^{*}$-Significant at 0.1 level; **-Significant at 0.05 level; ***-Significant at 0.01 level.

\section{Conclusions and Implications}

This study investigates the roles that green IS infrastructure and green culture play in green innovation. Based on the literature review, it develops a research model to capture the triadic relationships involving the direct effects of green IS infrastructure and green culture on green innovation as well as their indirect effects through the mediation of mutual alignments among the three. The hypothesized relationships were tested using survey observations collected from organizations in China. The results supported most of the hypotheses, and suggested that the relationships may vary across organizations of different sizes.

The major limitation of this study is that the observations were collected from a single country sample. In China, most organizations either voluntarily or are forced to embrace the opportunity of green innovation and green technology to sustain competitive advantages and comply with regulatory requirements. In this sense, the observations were valid. However, organizational culture may somewhat depend on national culture, which may vary significantly from one country to another [111]. Future studies may conduct cross-country analyses by collecting observations from multiple countries and regions.

Despite the limitations, this study yields some interesting and useful insights for researchers and practitioners. First, it helps answer the question of "what really matters to green innovation?" Compared with previous research, this study includes both green IS infrastructure as tangible resource and green culture as intangible resource. In addition to their direct effects from the resource-based view, it also investigates their indirect effects on green innovation based on the alignment perspective. 
Existing organizational studies on alignment typically include two factors and the fit between them. The findings based on the triadic relationships contribute to the literature by providing a more comprehensive understanding of how green technology and green culture interact with green innovation. Moreover, this study considered organizational characteristics, and revealed the moderating effect of organization size on the relationships.

The findings confirm that green innovation is indeed an extremely complex phenomenon. For an organization to succeed in achieving the ecological goals, it must establish sufficient green IS infrastructure, and align it with the endeavor. In addition, it must consider the existing organizational culture and cultivate new green culture. Organizations of different sizes may pursue different strategies to align green culture with green innovation and green IS infrastructure.

In particular, the results suggest that innovation-IS fit plays a more critical role than innovation-culture fit and IS-culture fit in maximizing green innovation effectiveness. Though green culture matters in its direct effect on the outcome, its alignments with green innovation and green IS infrastructure have little or even negative impacts. On the one hand, it is important for an organization to nurture green culture for long-term support; on the other hand, it is not worth the effort to adjust the culture to green innovation or technology. The direct practical implication is that decision-makers and managers can just focus on aligning green IS infrastructure with innovative endeavors. If they try to align green culture with green innovation and/or green IS infrastructure, the effort is likely to be neutralized.

The discussion of theoretical implication, on the other hand, requires a more in-depth comparison between technological and cultural resources in the context of green innovation. The formation of organizational culture is based on the uniformity of employee beliefs, and once a culture forms, it further strengthens the uniformity, leading to cultural inertia [112]. In theory, such an inertial force of organizational culture is likely to reduce the potential of IT implementation to engender organizational change [113]. The findings of this study not only provide empirical evidence of the dissonance in cultural alignment with technology and innovation, but also suggest that green culture is still inevitably associated with cultural inertia.

Rather, the IT infrastructure of an organization can be established in a much more flexible way for the purpose of obtaining and retaining competitive advantage in the fast changing world [114]. In this sense, aligning green IS infrastructure with green innovation makes more sense to organizations as it leads to predictable results in the near future. In contrast, when an organization eventually adjusts green culture to green innovation/technology, the endeavor may already have a new focus that demands further adjustment. Therefore, aligning culture to the moving targets of technology and innovation is mostly meaningless or even counter-productive.

Meanwhile, the direct effect of green culture on green innovation effectiveness suggests that organizations should cultivate organizational culture as early as possible to provide the supporting environment. In addition to such an intangible resource for green innovation, of course, organizations need to invest on green IS infrastructure as a tangible resource. The relatively stable cultural environment and relatively dynamic technological environment are both needed for the success of green innovation.

Though organization size does not have a direct impact on green innovation effectiveness (see Figure 3), the former moderates the effects of innovation-culture fit, IS-culture fit and innovation-IS fit on the latter as well as the effect of the latter on the environmental performance (see Table 5). The findings suggest that large and small/medium enterprises have their own advantages and disadvantages in green innovation endeavor. Bigger companies are more capable of integrating intangible cultural resource and tangible IS resource to promote green innovation. This explains why big organizations outperformed small and medium enterprises in terms of environmental performance in the sample. Small and medium enterprises, however, have the upper hand to quickly adopt green IS to support green innovation, yet are more susceptible to the negative effects of possible misalignment. This justifies the positive effect of innovation-IS fit and negative effect of innovation-culture fit for 
them in this study. The lack of significance of all alignment constructs for big organizations, on the other hand, suggests that they may miss the opportunity to embrace emerging technologies but also avoid bleeding-edge risks.

For policy makers, the findings suggest best practices to motivate and facilitate the green innovation of enterprises. On the one hand, environmental legislations push organizations to initiate green innovation for legal compliance; on the other hand, financial incentives such as tax benefit, low-interest loan and public funding provide a pull for infrastructure upgrade $[115,116]$. An enterprise needs to absorb and respond to such external incentives for them to take effects. The organization is likely to cultivate its internal green culture to adapt to the external legal environment, and establish its green IS infrastructure with the monetary support. With these two pillars in place, the company will experience less hindrance but gain more momentum in green innovation.

Acknowledgments: This study was funded by grants from the National Social Science Foundation of China (No. 15BGL040). The authors would like to express their sincere gratitude to the Editor and the anonymous reviewers for their insightful and constructive comments.

Author Contributions: Zhaojun Yang and Jun Sun developed the idea, motivation, and question of the paper and performed research at all stages. Yali Zhang and Ying Wang outlined the manuscript and made substantial contributions to data collection and analysis.

Conflicts of Interest: The authors declare no conflict of interest.

\section{Appendix A. Measurement Items}

\section{Functions of Green IS Infrastructure}

Please check the boxes corresponding to the functions of green IS infrastructure that are currently used in your organization for environmental protection and sustainable development:

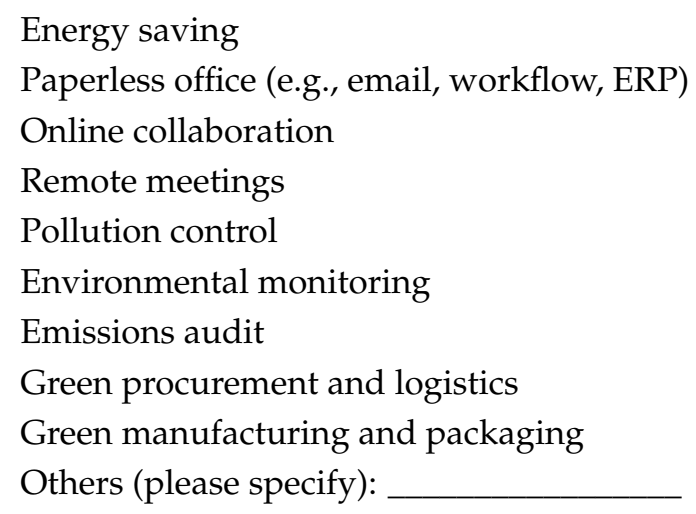

\section{Green IS Infrastructure}

Our organization implements Green IS infrastructure to...

\section{Pollution prevention}

... reduce overall consumption and emissions.

... reduce overall waste.

... reduce overall use of hazardous and toxic materials.

\section{Product stewardship}

... make material sourcing and acquisition more environmentally friendly.

... make product distribution and delivery more environmentally friendly.

... make product disassembly and remanufacturing routings more environmentally friendly. 


\section{Sustainable development}

... facilitate online collaboration (e.g., teleconferencing, electronic workflow) among employees.

... facilitate green operations across all the departments.

... facilitate management support and control for sustainable development.

... facilitate environmental compliance and auditing.

\section{Green Culture}

For the purpose of environment protection and sustainable development, ...

\section{Involvement}

... most people in our organization have input into the decisions that affect them.

... collaboration across functional roles is actively encouraged.

... there is continuous investment in the skills of employees.

\section{Consistency}

... there is a high level of agreement about the way that we do things in our organization.

... our approach of doing business is very consistent and predictable.

... there is a clear and consistent set of values that governs the way we do business.

\section{Adaptability}

... customers' comments and recommendations often lead to changes in our organization.

... our organization is very responsive and changes easily.

... learning is viewed critical for organizational improvement.

\section{Mission}

... our organization has a long-term purpose and direction.

... there is a shared vision of what our organization will be like in the future.

... we understand what needs to be done for us to succeed in the long run.

\section{Green Innovation Effectiveness}

Our organization excels in the following aspects of green innovation: ...

\section{Product innovation}

... using less or non-polluting/toxic materials.

... environment-friendly packaging for products.

... recovering and recycling end-of-life products.

... eco-labelling of products (green stickers like "Energy Star").

\section{Process innovation}

... consuming less resource (e.g., water, electricity, fuel) during production/use/disposal.

... reducing the emission of hazardous substances or waste during the manufacturing process.

... recycling, reusing and remanufacturing materials or parts.

... using cleaner or renewable technology to make savings (e.g., energy, water).

... reducing the use of raw materials during the manufacturing process.

\section{Management innovation}

... redesigning production and operation processes to enhance environmental efficiency 
... improving products/services to meet new environmental criteria or directives

... encouraging IT usage (e.g., paperless office) to reach ecological objectives

... establishing green strategy and ecological initiative

... adapting organizational structure to the needs of sustainable development

... enhancing managerial procedures (e.g., carbon footprint tracking) to support ecological decisions.

\section{Alignment}

\section{IS-Innovation Fit}

In facilitating the green innovation, our organization's green IS infrastructure is ...

... adequate

... appropriate

... compatible

... helpful

... valuable

\section{Culture-Innovation fit}

In facilitating the green innovation, our organization's green culture is

... adequate

... appropriate

... compatible

... helpful

... valuable

\section{IS-Culture Fit}

In facilitating the implementation and operation of green IS infrastructure, our organization's green culture is

... adequate

... appropriate

... compatible

... helpful

... valuable

\section{Organizational Performance}

Organizational performance is enhanced in terms of ...

\section{Economic performance}

... investment recovery

... cost containment

... profitability

... labour productivity

... inventory reduction

\section{Operational performance}

... product delivery

... product quality

... capacity utilization 
... cycle time reduction

... customer service

\section{Environmental performance}

... material reuse

... environmental compliance

... environment preservation

... reduction of hazardous wastes and emissions

... reduction of resource consumptions (e.g., energy, water, electricity, fuel)

Note: All items were of 5-level Likert scale in the questionnaire.

\section{References}

1. Fankhauser, S.; Bowen, A.; Calel, R.; Dechezleprêtre, A.; Grover, D.; Rydge, J.; Sato, M. Who will win the green race? In search of environmental competitiveness and innovation. Glob. Environ. Chang. 2013, 23, 902-913. [CrossRef]

2. Hillestad, T.; Xie, C.; Abimbola, T.; Haugland, S.A. Innovative corporate social responsibility: The founder's role in creating a trustworthy corporate brand through "green innovation". J. Prod. Brand Manag. 2010, 19, 440-451. [CrossRef]

3. Buhl, A.; Blazejewski, S.; Dittmer, F. The more, the merrier: Why and how employee-driven eco-innovation enhances environmental and competitive advantage. Sustainability 2016, 8, 946. [CrossRef]

4. Chang, C.-H. The influence of corporate environmental ethics on competitive advantage: The mediation role of green innovation. J. Bus. Ethics 2011, 104, 361-370. [CrossRef]

5. Chen, A.J.; Boudreau, M.-C.; Watson, R.T. Information systems and ecological sustainability. J. Syst. Inf. Technol. 2008, 10, 186-201. [CrossRef]

6. Jenkin, T.A.; Webster, J.; McShane, L. An agenda for 'green' information technology and systems research. Inf. Organ. 2011, 21, 17-40. [CrossRef]

7. Ar, I.M. The impact of green product innovation on firm performance and competitive capability: The moderating role of managerial environmental concern. Procedia Soc. Behav. Sci. 2012, 62, 854-864. [CrossRef]

8. Chen, Y.-S. The positive effect of green intellectual capital on competitive advantages of firms. J. Bus. Ethics 2007, 77, 271-286. [CrossRef]

9. Chiou, T.-Y.; Chan, H.K.; Lettice, F.; Chung, S.H. The influence of greening the suppliers and green innovation on environmental performance and competitive advantage in Taiwan. Transp. Res. Part E Logist. Transp. Rev. 2011, 47, 822-836. [CrossRef]

10. Tseng, M.-L.; Wang, R.; Chiu, A.S.; Geng, Y.; Lin, Y.H. Improving performance of green innovation practices under uncertainty. J. Clean. Prod. 2013, 40,71-82. [CrossRef]

11. Bernauer, T.; Engel, S.; Kammerer, D.; Sejas Nogareda, J. Determinants of green innovation-Ten years after porter's win-win proposition: How to study the effects of environmental regulation? Polit. Vierteljahresschr. 2007, 39, 323-341.

12. Qi, G.; Shen, L.; Zeng, S.; Jorge, O.J. The drivers for contractors' green innovation: An industry perspective. J. Clean. Prod. 2010, 18, 1358-1365. [CrossRef]

13. Weng, M.-H.; Lin, C.-Y. Determinants of green innovation adoption for small and medium-size enterprises (SMEs). Afr. J. Bus. Manag. 2011, 5, 9154-9163.

14. Gluch, P.; Gustafsson, M.; Thuvander, L. An absorptive capacity model for green innovation and performance in the construction industry. Constr. Manag. Econ. 2009, 27, 451-464. [CrossRef]

15. Qi, G.; Zeng, S.; Tam, C.; Yin, H.; Zou, H. Stakeholders' influences on corporate green innovation strategy: A case study of manufacturing firms in china. CSR. Environ. Manag. 2013, 20, 1-14.

16. Chang, C.-H.; Chen, Y.-S. Green organizational identity and green innovation. Manag. Decis. 2013, 51, 1056-1070. [CrossRef]

17. Bengtsson, F.; Ågerfalk, P.J. Information technology as a change actant in sustainability innovation: Insights from Uppsala. J. Strateg. Inf. Syst. 2011, 20, 96-112. [CrossRef] 
18. Faucheux, S.; Nicolaï, I. It for green and green it: A proposed typology of eco-innovation. Ecol. Econ. 2011, 70, 2020-2027. [CrossRef]

19. Melville, N.P. Information systems innovation for environmental sustainability. MIS Q. 2010, 34, 1-21.

20. Cabrera, Á.; Cabrera, E.F.; Barajas, S. The key role of organizational culture in a multi-system view of technology-driven change. Int. J. Inf. Manag. 2001, 21, 245-261. [CrossRef]

21. Russo, M.V.; Fouts, P.A. A resource-based perspective on corporate environmental performance and profitability. Acad. Manag. J. 1997, 40, 534-559. [CrossRef]

22. Collis, D.J.; Montgomery, C.A. Competing on resources: Strategy in the 1990s. Harv. Bus. Rev. 1995, 73, 118-129.

23. Büschgens, T.; Bausch, A.; Balkin, D.B. Organizational culture and innovation: A Metas-Strategy Review. J. Prod. Innov. Manag. 2013, 30, 763-781. [CrossRef]

24. Claver, E.; Llopis, J.; Garcia, D.; Molina, H. Organizational culture for innovation and new technological behavior. J. High Technol. Manag. Res. 1998, 9, 55-68. [CrossRef]

25. Khazanchi, S.; Lewis, M.W.; Boyer, K.K. Innovation-supportive culture: The impact of organizational values on process innovation. J. Oper. Manag. 2007, 25, 871-884. [CrossRef]

26. Naranjo-Valencia, J.C.; Jiménez-Jiménez, D.; Sanz-Valle, R. Innovation or imitation? The role of organizational culture. Manag. Decis. 2011, 49, 55-72. [CrossRef]

27. Porter-O'Grady, T.; Malloch, K. Innovation: Driving the green culture in healthcare. Nurs. Adm. Q 2010, 34, E1-E5. [CrossRef] [PubMed]

28. Wirtenberg, J. Building a Culture for Sustainability: People, Planet, and Profits in a New Green Economy; ABC-CLIO: Santa Barbara, CA, USA, 2014.

29. Fussler, C.; James, P. A Breakthrough Discipline for Innovation and Sustainability; Pitman Publishing: London, UK, 1996.

30. Brunnermeier, S.B.; Cohen, M.A. Determinants of environmental innovation in us manufacturing industries. J. Environ. Econ. Manag. 2003, 45, 278-293. [CrossRef]

31. Geffen, C.A.; Rothenberg, S. Suppliers and environmental innovation: The automotive paint process. Int. J. Oper. Prod. Manag. 2000, 20, 166-186. [CrossRef]

32. Carrión-Flores, C.E.; Innes, R. Environmental innovation and environmental performance. J. Environ. Econ. Manag. 2010, 59, 27-42. [CrossRef]

33. Verghese, K.; Lewis, H. Environmental innovation in industrial packaging: A supply chain approach. Int. J. Prod. Res. 2007, 45, 4381-4401. [CrossRef]

34. Oltra, V.; Saint Jean, M. Sectoral systems of environmental innovation: An application to the French automotive industry. Technol. Forecast. Soc. Chang. 2009, 76, 567-583. [CrossRef]

35. Theyel, G. Management practices for environmental innovation and performance. Int. J. Oper. Prod. Manag. 2000, 20, 249-266. [CrossRef]

36. Horbach, J. Determinants of environmental innovation-New evidence from German panel data sources. Res. Policy 2008, 37, 163-173. [CrossRef]

37. Foxon, T.; Pearson, P. Overcoming barriers to innovation and diffusion of cleaner technologies: Some features of a sustainable innovation policy regime. J. Clean. Prod. 2008, 16, S148-S161. [CrossRef]

38. Schiederig, T.; Tietze, F.; Herstatt, C. Green innovation in technology and innovation management-An exploratory literature review. RED Manag. 2012, 42, 180-192.

39. Rennings, K. Redefining innovation-Eco-innovation research and the contribution from ecological economics. Ecol. Econ. 2000, 32, 319-332. [CrossRef]

40. Hellström, T. Dimensions of environmentally sustainable innovation: The structure of eco-innovation concepts. Development 2007, 15, 148-159. [CrossRef]

41. Bartlett, D.; Trifilova, A. Green technology and eco-innovation: Seven case-studies from a russian manufacturing context. J. Manuf. Technol. Manag. 2010, 21, 910-929. [CrossRef]

42. Lee, V.-H.; Ooi, K.-B.; Chong, A.Y.-L.; Seow, C. Creating technological innovation via green supply chain management: An empirical analysis. Expert Syst. Appl. 2014, 41, 6983-6994. [CrossRef]

43. Amores-Salvadó, J.; Martín-de Castro, G.; Navas-López, J.E. Green corporate image: Moderating the connection between environmental product innovation and firm performance. J. Clean. Prod. 2014, 83, 356-365. [CrossRef] 
44. Arundel, A.; Kemp, R. Measuring Eco-Innovation. Available online: http:/ / econpapers.repec.org/paper/ taswpaper/10062.htm (accessed on 2 August 2017).

45. Carrillo-Hermosilla, J.; del Río, P.; Könnölä, T. Diversity of eco-innovations: Reflections from selected case studies. J. Clean. Prod. 2010, 18, 1073-1083. [CrossRef]

46. Zailani, S.; Govindan, K.; Iranmanesh, M.; Shaharudin, M.R.; Chong, Y.S. Green innovation adoption in automotive supply chain: The Malaysian case. J. Clean. Prod. 2015, 108, 1115-1122. [CrossRef]

47. Jakobsen, S.; Clausen, T. Comparing the innovation process in environmental and non-environmental firms: A look at barriers to innovation. In Proceedings of the DRUID Society Conference, Copenhagen, Denmark, 16-18 June 2014.

48. Cuerva, M.C.; Triguero-Cano, Á.; Córcoles, D. Drivers of green and non-green innovation: Empirical evidence in low-tech smes. J. Clean. Prod. 2014, 68, 104-113. [CrossRef]

49. Jakobsen, S.; Clausen, T.H. Innovating for a greener future: The direct and indirect effects of firms' environmental objectives on the innovation process. J. Clean. Prod. 2015, 128, 131-141. [CrossRef]

50. Fok, L.Y.; Zee, S.M.; Hartman, S.J. Relationships among individual green orientation, employee perceptions of organizational commitment to the green movement, and organizational culture: A comparative study of Jamaica and the United States. J. Organ. Cutl. Commun. Confl. 2012, 16, 125-144.

51. Fraj, E.; Martínez, E.; Matute, J. Green marketing strategy and the firm's performance: The moderating role of environmental culture. J. Strateg. Mark. 2011, 19, 339-355. [CrossRef]

52. Moreton, K.; Williamson, D.; Lynch-Wood, G. An emergent typology of strategy, innovation and culture as determinants of business performance in small and medium-sized environmental enterprises. In Proceeding of the 11th Annual International Sustainable Development Research Conference, Helsinki, Finland, 6-8 June 2005.

53. Sugita, M.; Takahashi, T. Influence of corporate culture on environmental management performance: An empirical study of Japanese firms. CSR Environ. Manag. 2015, 22, 182-192. [CrossRef]

54. McLean, L.D. Organizational culture's influence on creativity and innovation: A review of the literature and implications for human resource development. ADHR 2005, 7, 226-246. [CrossRef]

55. Qin, D.; Zhao, D.; Yao, L. Enterprise culture and technological innovation capability from the perspective of resources. Cross Cult. Comm. 2013, 9, 92.

56. Steiber, A.; Alänge, S. A corporate system for continuous innovation: The case of Google Inc. Eur. J. Innov. Manag. 2013, 16, 243-264. [CrossRef]

57. Chen, Y.-S.; Chang, C.-H.; Wu, F.-S. Origins of green innovations: The differences between proactive and reactive green innovations. Manag. Decis. 2012, 50, 368-398. [CrossRef]

58. Sarkis, J.; Koo, C.; Watson, R.T. Green information systems \& technologies-this generation and beyond: Introduction to the special issue. Inf. Syst. Front. 2013, 15, 695-704.

59. Watson, R.T.; Boudreau, M.-C.; Chen, A.J. Information systems and environmentally sustainable development: Energy informatics and new directions for the IS community. MIS Q. 2010, 34, 23-38.

60. Tarafdar, M.; Gordon, S.R. Understanding the influence of information systems competencies on process innovation: A resource-based view. J. Strateg. Inf. Syst. 2007, 16, 353-392. [CrossRef]

61. Anaya, L.; Dulaimi, M.; Abdallah, S. An investigation into the role of enterprise information systems in enabling business innovation. Bus. Process Manag. J. 2015, 21, 771-790. [CrossRef]

62. Ganotakis, P.; Hsieh, W.-L.; Love, J.H. Information systems, inter-functional collaboration and innovation in taiwanese high-tech manufacturing firms. Prod. Plan. Contr. 2013, 24, 837-850. [CrossRef]

63. Chaparro-Peláez, J.; Pereira-Rama, A.; Pascual-Miguel, F.J. Inter-organizational information systems adoption for service innovation in building sector. J. Bus. Res. 2014, 67, 673-679. [CrossRef]

64. Gallivan, M.; Srite, M. Information technology and culture: Identifying fragmentary and holistic perspectives of culture. Inf. Organ. 2005, 15, 295-338. [CrossRef]

65. Cui, T.; Ye, H.J.; Teo, H.H.; Li, J. Information technology and open innovation: A strategic alignment perspective. Inf. Manag. 2015, 52, 348-358. [CrossRef]

66. Venkatraman, N. The concept of fit in strategy research: Toward verbal and statistical correspondence. Acad. Manag. Rev. 1989, 14, 423-444.

67. Ashurst, C.; Freer, A.; Ekdahl, J.; Gibbons, C. Exploring it-enabled innovation: A new paradigm? Int. J. Inf. Manag. 2012, 32, 326-336. [CrossRef] 
68. Lee, A. Researching MIS-in Rethinking Management Information Systems; Currie, W., Galliers, B., Eds.; Oxford University Press: Oxford, UK, 1999.

69. Pellissier, R. A conceptual framework for the alignment of innovation and technology. J. Technol. Manag. Innov. 2008, 3, 67-77. [CrossRef]

70. Carcary, M.; Doherty, E.; Thornley, C. Business innovation and differentiation: Maturing the IT capability. IT Prof. 2015, 17, 46-53. [CrossRef]

71. Al-Mashari, M. Innovation through information technology (IT) enabled business process management (BPM): A review of key issues. Int. J. Innov. Learn. 2006, 3, 403-415. [CrossRef]

72. Müller, S.; Møller, E.; Nygaard, T. IT-enabled process innovation: A literature review. In Proceedings of the 18th AMCIS, Washington, DC, USA, 9-11 August 2012.

73. Chae, B.K. A complexity theory approach to IT-enabled services (IESs) and service innovation: Business analytics as an illustration of IES. Decis. Support Syst. 2014, 57, 1-10. [CrossRef]

74. Huang, J.-C.; Liu, J.-C. Exploration for the relationship between innovation, it and performance. J. Intellect. Cap. 2000, 6, 237-252. [CrossRef]

75. Ahmed, P.K. Culture and climate for innovation. Eur. J. Innov. Manag. 1998, 1, 30-43. [CrossRef]

76. Jaruzelski, B.; Loehr, J.; Holman, R. Why culture is key. Strateg. Bus. 2011, 65, 1-17.

77. Harrington, S.J.; Guimaraes, T. Corporate culture, absorptive capacity and IT success. Inf. Organ. 2005, 15, 39-63. [CrossRef]

78. Denison, D.R.; Mishra, A.K. Toward a theory of organizational culture and effectiveness. Organ. Sci. 1995, 6, 204-223. [CrossRef]

79. Schein, E.H. Organizational culture. Am. Psychol. 1990, 45, 109-119. [CrossRef]

80. Wang, C.L.; Rafiq, M. Ambidextrous organizational culture, contextual ambidexterity and new product innovation: A comparative study of UK and Chinese high-tech firms. Br. J. Manag. 2014, 25, 58-76. [CrossRef]

81. Jackson, S. Organizational culture and information systems adoption: A three-perspective approach. Inf. Organ. 2011, 21, 57-83. [CrossRef]

82. Leidner, D.E.; Kayworth, T. A review of culture in information systems research: Toward a theory of information technology culture conflict. MIS Q. 2006, 30, 357-399.

83. Bajwa, D.S.; Lewis, L.F. Does size matter? An investigation of collaborative information technology adoption by us firms. J. Inf. Technol. Theory Appl. 2003, 5, 29-46.

84. Yao, J.E.; Xu, X.; Liu, C.; Lu, J. Organizational size: A significant predictor of it innovation adoption. J. Comput. Inf. Syst. 2003, 43, 76-82.

85. Chuang, T.-T.; Rutherford, M.W.; Lin, B. Owner/manager characteristics, organisational characteristics and it adoption in small and medium enterprises. Int. J. Manag. Enterp. Dev. 2007, 4, 619-634. [CrossRef]

86. Cameron, K.S.; Quinn, R.E. Diagnosing and Changing Organizational Culture: Based on the Competing Values Framework; Jossey-Bass: New York, NY, USA, 2011.

87. Choo, C.W.; Bergeron, P.; Detlor, B.; Heaton, L. Information culture and information use: An exploratory study of three organizations. J. Assoc. Inf. Sci. Technol. 2008, 59, 792-804. [CrossRef]

88. Yang, Y.-C.; Hsu, J.-M. Organizational process alignment, culture and innovation. Afr. J. Bus. Manag. 2010, 4, 2231-2240.

89. Denison, D.R.; Haaland, S.; Goelzer, P. Corporate culture and organizational effectiveness: Is there a similar pattern around the world? Organ. Dyn. 2003, 3, 205-227.

90. Southern, G.; Murray, A.U. Quality information management: The way to a better company culture. Inf. Manag. Comput. Secur. 1994, 2, 32-35. [CrossRef]

91. Silvius, A.G.; Smit, J.; Driessen, H. The relationship between organizational culture and the alignment of business and it. In Proceedings of the AMCIS, Lima, Peru, 12-15 August 2010; p. 186.

92. Claver, E.; Llopis, J.; Reyes González, M.; Gascó, J.L. The performance of information systems through organizational culture. Inf. Technol. People 2001, 14, 247-260. [CrossRef]

93. Huang, J.-W.; Li, Y.-H. A Study of Environmental Innovation Strategy, Resource Alignment, and Green Innovation Performance, Academy of Management Proceedings. 2014. Available online: http:/ / proceedings. aom.org/content/2014/1/13674.short (accessed on 2 August 2017).

94. Chen, Y.-S.; Lai, S.-B.; Wen, C.-T. The influence of green innovation performance on corporate advantage in Taiwan. J. Bus. Ethics 2006, 67, 331-339. [CrossRef] 
95. Damanpour, F.; Aravind, D. Managerial innovation: Conceptions, processes, and antecedents. Manag. Organ. Rev. 2012, 8, 423-454. [CrossRef]

96. Chen, Y.-S.; Lin, Y.-H.; Lin, C.-Y.; Chang, C.-W. Enhancing green absorptive capacity, green dynamic capacities and green service innovation to improve firm performance: An analysis of structural equation modeling (SEM). Sustainability 2015, 7, 15674-15692. [CrossRef]

97. Hojnik, J.; Ruzzier, M. The driving forces of process eco-innovation and its impact on performance: Insights from slovenia. J. Clean. Prod. 2016, 133, 812-825. [CrossRef]

98. Ryszko, A. Proactive environmental strategy, technological eco-innovation and firm performance-Case of poland. Sustainability 2016, 8, 156. [CrossRef]

99. Weng, H.R.; Chen, J.; Chen, P. Effects of green innovation on environmental and corporate performance: A stakeholder perspective. Sustainability 2015, 4997-5026. [CrossRef]

100. Gholami, R.; Sulaiman, A.B.; Ramayah, T.; Molla, A. Senior managers' perception on green information systems (IS) adoption and environmental performance: Results from a field survey. Inf. Manag. 2013, 50, 431-438. [CrossRef]

101. Lin, T.-C.; Huang, C.-C. Understanding knowledge management system usage antecedents: An integration of social cognitive theory and task technology fit. Inf. Manag. 2008, 45, 410-417. [CrossRef]

102. Green, K.W., Jr.; Zelbst, P.J.; Meacham, J.; Bhadauria, V.S. Green supply chain management practices: Impact on performance. Supply Chain Manag. 2012, 17, 290-305. [CrossRef]

103. Lee, S.M.; Tae Kim, S.; Choi, D. Green supply chain management and organizational performance. Ind. Manag. Data Syst. 2012, 112, 1148-1180. [CrossRef]

104. Daugherty, P.J.; Richey, R.G.; Genchev, S.E.; Chen, H. Reverse logistics: Superior performance through focused resource commitments to information technology. Transp. Res. Part E 2005, 41, 77-92. [CrossRef]

105. Armstrong, J.S.; Overton, T.S. Estimating nonresponse bias in mail surveys. J. Market. Res. 1977, $396-402$. [CrossRef]

106. Podsakoff, P.M.; MacKenzie, S.B.; Lee, J.-Y.; Podsakoff, N.P. Common method biases in behavioral research: A critical review of the literature and recommended remedies. J. Appl. Psychol. 2003, 88, 879-903. [CrossRef] [PubMed]

107. Podsakoff, P.M.; MacKenzie, S.B.; Podsakoff, N.P. Sources of method bias in social science research and recommendations on how to control it. Annu. Rev. Psychol. 2012, 63, 539-569. [CrossRef] [PubMed]

108. Richardson, H.A.; Simmering, M.J.; Sturman, M.C. A tale of three perspectives: Examining post hoc statistical techniques for detection and correction of common method variance. Organ. Res. Methods 2009, 12, 762-800. [CrossRef]

109. Wetzels, M.; Odekerken-Schröder, G.; van Oppen, C. Using pls path modeling for assessing hierarchical construct models: Guidelines and empirical illustration. MIS Q. 2009, 177-195.

110. Hair, J.F., Jr.; Hult, G.T.M. A Primer on Partial Least Squares Structural Equation Modeling (PLS-SEM); Sage Publications: Thousand Oaks, CA, USA, 2013.

111. Hemmert, M.; Bstieler, L.; Okamuro, H. Bridging the cultural divide: Trust formation in university-industry research collaborations in the US, Japan, and South Korea. Technovation 2014, 34, 605-616. [CrossRef]

112. Carrillo, J.D.; Gromb, D. Cultural inertia and uniformity in organizations. J. Law Econ. Organ. 2006, 23, 743-771.

113. Cooper, R.B. The inertial impact of culture on it implementation. Inf. Manag. 1994, 27, 17-31.

114. Byrd, T.A.; Turner, D.E. An exploratory examination of the relationship between flexible it infrastructure and competitive advantage. Inf. Manag. 2001, 39, 41-52.

115. Dooley, R.S.; Fryxell, G.E. Are conglomerates less environmentally responsible? An empirical examination of diversification strategy and subsidiary pollution in the U.S. Chemical industry. J. Bus. Ethics 1999, 21, 1-14.

116. Lee, S.Y. Drivers for the participation of small and medium-sized suppliers in green supply chain initiatives. SCM 2013, 13, 185-198.

(C) 2017 by the authors. Licensee MDPI, Basel, Switzerland. This article is an open access article distributed under the terms and conditions of the Creative Commons Attribution (CC BY) license (http:/ / creativecommons.org/licenses/by/4.0/). 